\author{
ロータリエンジンのアペックスシール挙動* \\ （4 変位センサによる測定）
}

\author{
松浦健坚*1

\section{Measurements of Apex Seal Behavior in a Rotary Engine Using Four Displacement Sensors}

\author{
Kenji MATSUURA
}

\begin{abstract}
Behavior measurements of an apex seal of three piece slanted horizontal split type were made, using an overhanging eccentric shaft type single rotor engine equipped with a multichannel packaged slip ring. To analyze the behavior, a computer plotting program was developed, by means of which the sequences of the configuration of top and bottom parts in the slot at given eccentric shaft angles were plotted on the trochoidal curves from the measured displacement data. The measurement results revealed the details of the behavior. Under high working chamber pressure, the top part of the leading apex seal is flush with the leading side of the slot, while that of the trailing apex seal is considerably tilted with respect to the trailing edge of the slot.
\end{abstract}

Key Words: Internal Combustion Engine, Wankel Rotary Engine, Apex Seal, Seal Behavior, Magnetic Induction, Measurement Method

\section{1.まえがき}

ロータリエンジンの作動室からのガス漏れは掞もに アペックスシールからでその㵢れ面積を小さくする ことによーて性能がよくなる可能性があると見積もら れているい。アヘッッスシールは1片式アルミニりム 含浸力一ボン製(2) (1 片式)から，2片式チル化鋳鉄製 (2片式)，さらに3\%式上下斜分割チル化鋳鉄製 $(3$ 片 式)到人と改良されてきた。1片式と2片式のように ト下・体形はシール淦で傾き，アペックスシールの第 一次気密面，古なおち，アペックスシールとシール满 側面との気湾面が四接触状態とならないため，そこを 通過して隣空へガ久䊖れが生じると考えられた。その ため，3版式はシールをに下に斜めに分割し，シール

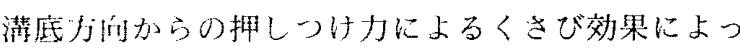
て、シール满側面上面接触させて気密を改善すること を意図して開発きれたものである(3).しかし，3片式 0)場会もアペックスシールを通過するガス漏れが存在: することが，レーザドッブラー流速測定法によるモー タリングの場命の央駼的研究(4)によって示されてい

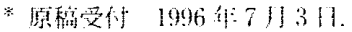

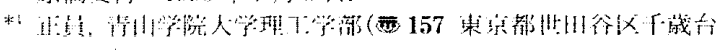
$6161)$.
弓.

アペックスシールの挙動の実態を知ることは, ケ゚゚ ックスシールを通過するガス漏れや悸擦搷头の低減に 上るトルクの改善，燃料消资率の低隇，酎久性:の向１： などのために非常に重要であるが、ロータからの訃測 信产の学山が異易でないため，4変位センサに上る測 定は行われていなかった。著者らの徒来の测定 ${ }^{(5)}$ は2 湖の変位センサによるものであったので，上部，下部 シールそれぞれのシール溝での傾きなどに関する挙動 の実態の把握は十分でなく，解明寸る必要があった。

本研究では，ロー夕上の部測信当のエンジン外部へ の尊出が困難なロータリエンジンについて，アペッタ スシールに関する条件を变えることなく，訃測信号を 多チャネルで，エンジン外部に取り出すことのできる 高速回転が叮能な計測用エンジンを開発し，上部，下 部シール月に上卜にそれぞれ 2 個ずつ合計 4 個の変位 センサをシール瑇側面に取付けてアペックスシールの 挙動在測定し，それらの変位測定值をパーソナルコン

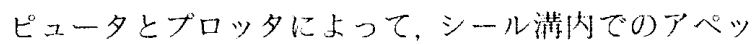
クスシールの姿勢を任意の主軸角度のロータハウジン グ位罚に対して表示できるようにし，上下斜分制 3 个 式ソベックスシールの第...次気滵面の举動特性を明ら かにした。 
記 号

$a:$ アペックスシールの先端半径
$C:$ ロータハウジングとアペックスシールの接触 点のシール溝先端からの高さ

$e$ :トロコイドの偏心量

$f_{11}, f_{12}, f_{23}, f_{33}: P_{11}, P_{12}, P_{23}, P_{33}$ によって生じる力

$f_{1 x}, f_{1 y}, f_{3 x}, f_{3 y}, f_{4 x}, f_{4 y}:$ それぞれ $P_{1}, P_{3}, P_{4}$ によ って生じる $x, y$ 方向の力

$f_{2}: P_{2}$ によって生じる力

$f_{S}:$ スプリングカ

$F_{R}:$ : ールの半径方向 $(y$ 方向) の慣性力

$F_{T}:$ シールのシール淦に垂直方向の慣性力

$F_{x}$ : シール溝に垂直な方向 ( $x$ 方向) の合力

$F_{y}:$ :ールル溝方向 ( $y$ 方向) の合力

$G_{1}, G_{2}:$ 上部, 下部シールの重心

$h_{1}, h_{2}$ : 上部シールのリーディング面とトレーリング 面の下端からシール溝先端までの高さ

$h_{3}, h_{4}$ : 下部シールのリーディング面とトレーリング 面の高さ

$h_{y 1}, h_{y 2}$ : 上部, 下部シールのトレーリング側下端から 重心までの高さ

$M:$ シールの質量

$M_{A} M_{B}:$ 点 $\mathrm{A}, \mathrm{B}$ まわりのモーメント

$O_{A}:$ アペックスシールの弧の中心

$P_{1}:$ リーディング作動室の圧力

$P_{2}:$ アペックスシールの背室 (溝底) の圧力

$P_{3}:$ トレーリング作動室の圧力

$P_{4}:$ 上部, 下部シール間の压力

$P_{11}, P_{12}, P_{23}, P_{33}: h_{1}, h_{4}, h_{3}, h_{2}$ の部分に作用する压 †

$R$ :トロコイドの創成半径

$R_{1}:$ ロータハウジング面の抗力

$R_{2}$ : シール溝のリーディング面の反力(上部シー ルト端から $y_{2}$ の高さの位置)

$R_{3}$ : シール溝のトレーリング面の反力 (上部シー ル下端から $y_{1}$ の高さの位置)

$R_{4}$ ：上部シール下端部と下部シール, トレーリン グ上端の反力

$R_{5}$ : シール瑇のトレーリング面の反力(下部シー ル下端から $y_{3}$ の高さの位置)

$R_{6}$ : シール浑のリーディング面の反力(下部シー ル下端から $y_{4}$ の高さの位置)

$R_{g}:$ ロータの中心からシールの重心までの距離

$t:$ アペックスシールの厚さ

$t_{1}, t_{2}:$ ロータハウジングとアペックスシールの接点
までのシールのリーディング面とトレーリン グ面からの距離

$t_{x 1}, t_{x 2}$ : 上部, 下部シールのトレーリング面から重心 までの距離

$\beta:$ シール斜面の傾き角度

$\theta ：$ 主軸回転角度

$\phi:$ 摇動角

$\mu_{D}:$ 動摩擦係数

$\mu_{S}$ : 静止摩擦係数 $(x, y$ 方向の摩擦力を正とす る, 斜面部分は反力の方向で摩擦力の方向は 決まる)

$\omega:$ 主軸角速度

\section{2. 実験装置および方法}

$2 \cdot 1$ 実験用片持式単ロータロータリエンジン 通常の構造のロータリエンジンでは, 口ータ上の信 号を多チャネルでエンジン外部に取り出すことは容易 ではない，そこで，ロータの内歯歯車と反刘側のロー 夕の側面の中央部を外部に露出させた実験用片持式口 ータリエンジンを開発して用いていだ(5)(6). しかし, その構造では主軸が固定外歯歯車を貫通できる直径で なければならないため，高速回転時にはたわみが大き くなり，ロー夕側面が損傷を受ける場合があることが おかったそここで，固定外菊㐘車を主軸を通さなくて よい配置にし，便宜上，ロータベアリングを用いて， 主軸径をロー夕軸径と同じにして強度を増した。その 実験用片持単ロータロータリエンジンの主要断面図を 図 1 に示す。

このエンジンは, エキセントリックシャフト(16)の一 端にロー夕(13)が片持されているので, ロー夕側面の中 央部を露出させることができる，信号の導出装置は口 ータサイドカバー12)の中心付けた並列六重巻のコイ ルスプリング(3)とそのガイド(2)とスリップリング(10 上 り成っている，ロータ0公転運動はコイルスプリング の弾性に吸収させ，自転運動のみがスリップリングに 伝達される。それ的え，スリップリングはロータと同 じくエキセントリックシャフトの回転速度の $1 / 3$ で回 転する。ロータ上の計測信号はコイルスブリング内の リード線とスリップリングを経てエンジン外部へと導 出される。コイルスプリングと変位センサホルダを付 けたロー夕側面の外観を図 2 に示す。この実験用エン ジンによって実機のアペックスシールの諸条件を変え ることなく,アペックスシールの挙動を測定できる。 エキセントリックシャフトとバランスウエイトを除く エンジンの主要構成部はマツダ製 $13 \mathrm{~B}$ 形ロータリエ ンジンの部品を改造して流用した。供試ロータリエン 


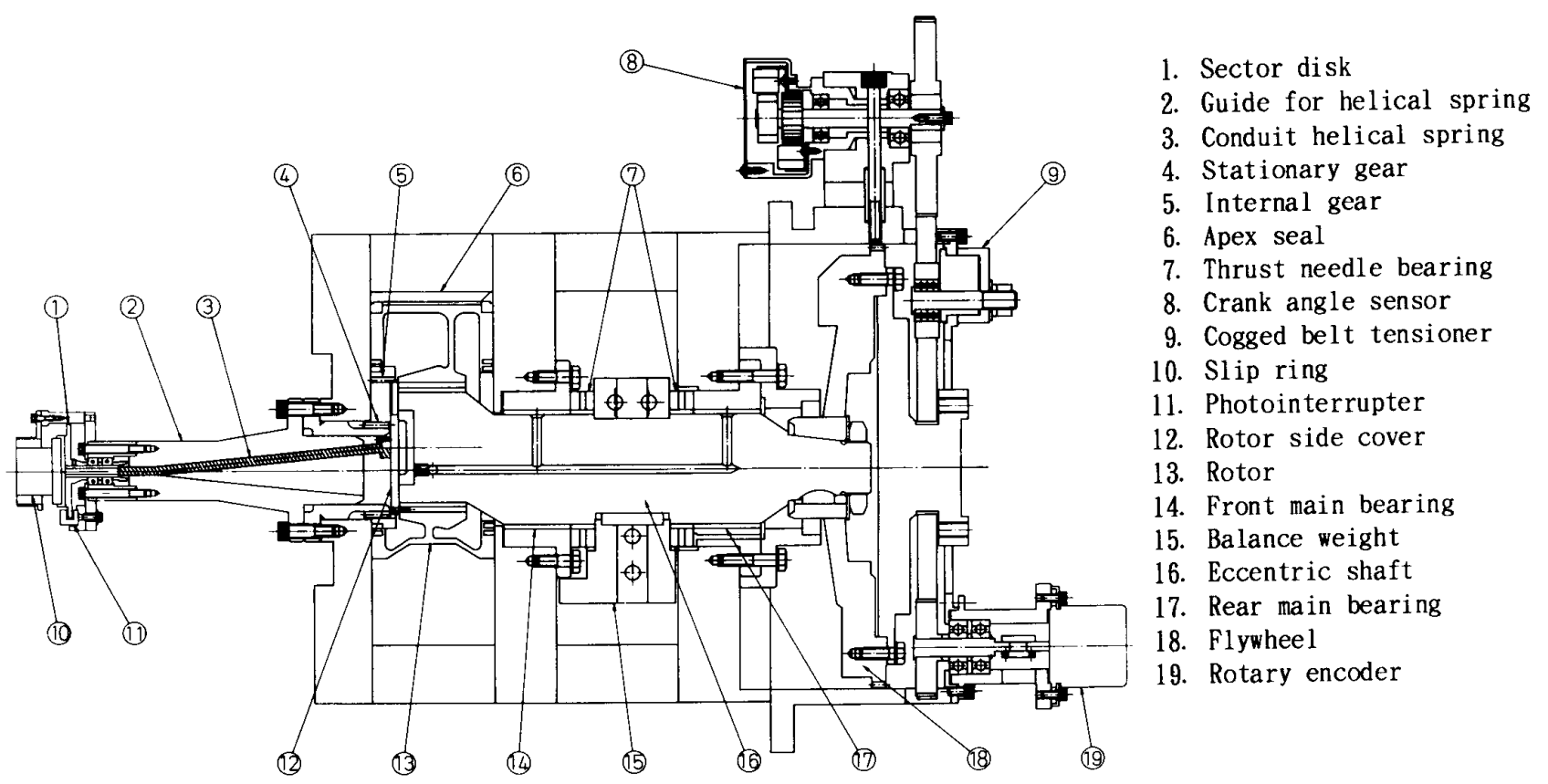

Fig. 1 Primary longitudinal section of experimental engine

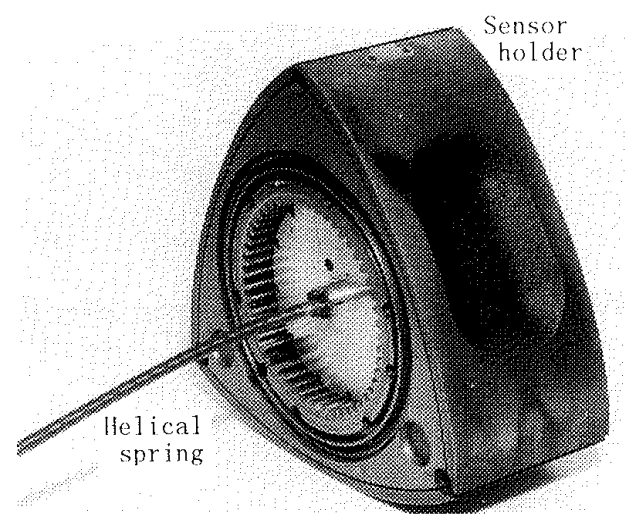

Fig. 2 Side view of rotor with displacement sensor holder and helical spring installed

ジンの主要諸元を表 1 に示す.

ロータベアリングとメインベアリングの潤滑および ロータの油冷のため, エキセントリックシャフト端の 噴出孔へのオイルの供給は外部設置の電動オイルポン プによる強制压送循環給油方式を採用し，水冷式才イ ルクーラによって油温を制御した。アペックスシール およびシール類の潤滑油は, 外部設置の電動メタリン グオイルポンプによって吸気管とロータハウジングに 装着されているチェックバルブによって吸気および直 接ロータハウジング面にそれぞれ供給した。燃料のガ ソリンは吸気管噴射方式で供給した。点火はCDI 方 式である.これらの制御のためにエンジン後部のコク ドベルトで駆動されるロータリエンコーダの信号を用 いた。作動室圧測定用インジケータの取付位置, 点火 プラグ孔，オイル供給孔，吸排気口の位置を任意の 1
Table 1 Primary specifications of experimental rotary engine

\begin{tabular}{|l|l|c|}
\hline & Material & \multicolumn{2}{|c|}{ Chilled cast iron } \\
& Nose radius & $2.0 \mathrm{~mm}$ \\
Apex seal & Overhang & $1.0 \mathrm{~mm}$ \\
& Thickness & $3.0 \mathrm{~mm}$ \\
& Configuration & Three-piece \\
& Mass & $13.5 \mathrm{~g}$ \\
& Clearance & $0.06 \mathrm{~mm}$ \\
& Underseal volume & $425 \mathrm{~mm}^{3}$ \\
\hline Rotor & Mass for balancing & $5465 \mathrm{~g}$ \\
\hline Rotor & Eccentricity & $15 \mathrm{~mm}$ \\
housing & Generating radius & $102 \mathrm{~mm}$ \\
& Equidistance & $3 \mathrm{~mm}$ \\
& Width & $80 \mathrm{~mm}$ \\
\hline Intake & Opening & $32^{\circ} \mathrm{ATDC}$ \\
(Side) & Closing & $40^{\circ} \mathrm{ABDC}$ \\
\hline Exhaust & Opening & $71^{\circ} \mathrm{BBDC}$ \\
(Peripheral) & Closing & $48^{\circ} \mathrm{ATDC}$ \\
& Type & Single port \\
\hline Displacement & & $654 \mathrm{mlXl}$ \\
\hline Compression & ratio & 9.4 \\
\hline
\end{tabular}

個のアペックスシールがロータハウジング上を移動す る場合の主軸角度で, トロコイドの長軸の圧縮側を主 軸角度 $\theta$ の基準角度 $\left(\theta=0^{\circ}\right)$ として図 3 に示寸。ア ペックスシール位置は以後この主軸角度で示す。

$2 \cdot 2$ アペックスシールおよび変位測定系供試 アペックスシールは上下斜分割形 3 片式で図 4 に示す ように $60^{\circ}$ の角度で上下斜めに分割されて構成されて いる。これはマツダ製 $13 \mathrm{~B}$ 形の既製の $3 \mathrm{~mm}$ 厚の上 下一体形アペックスシールから製作した。被測定アペ ックスシールの上部シールと下部シールそれぞれの上 方と下方の変位を測定するため 4 個のセンサを用い 


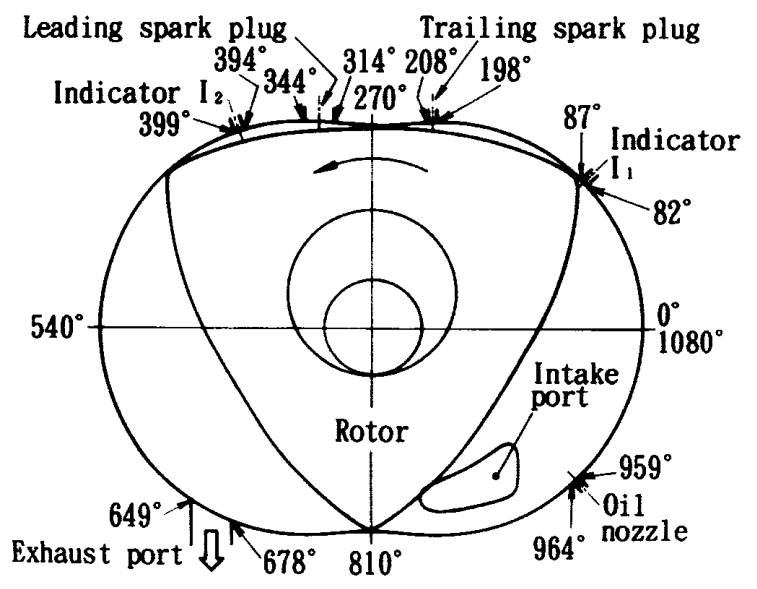

Fig. 3 Location of pressure indicators, spark plugs, intake and exhaust ports and oil supply hole

79.7

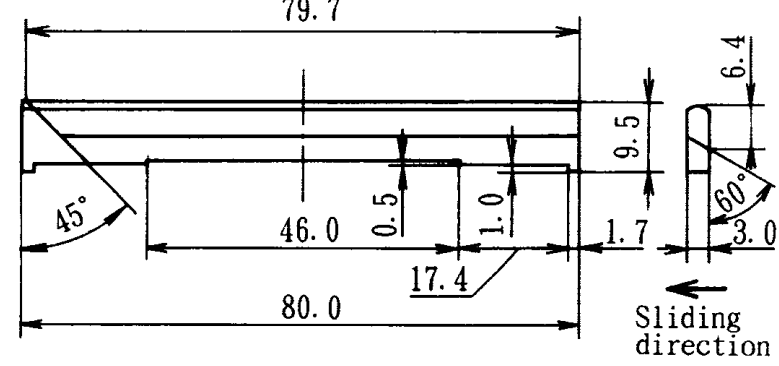

Fig. 4 Three piece slanted horizontal split apex seal

た。上部およびト部シールに対する上ドのセンサをシ ール满の長さ方向の同じ位置でシール溝側面のト下に 取付けられる程度に小さくすることができなかったの で，図5に示すように横並びの上下にセンサを埋め込 んで配置したホルダを、シール溝のリーディング側面 に取付けた。これらの変位センサはインダクタンス変 化式である. 叫形のフェライトコアにコイルを巻いた もので，既報 ${ }^{(5)(6)}$ のものと同形式であるが，測定部先 端の面積を 1.5 倍にして感度を增した。なおフェライ トコアの軍さは従来と同じ $1 \mathrm{~mm}$ である。図 6 に示 す電磁誘導法による変位测定回路を用いた。送信コイ ルから高周波を共振コイルを隔てて，受信コイルに送 り，アペックスシールの変位変化によって生じるイン ピーダンス変化を受信コイルを経て検出することによ り，変位測定ができる、シール溝でのアペックスシー ルのセンサに平行な変位に対する各セン少の感度は 0.01〜0.06 mm のシックネスゲージで, 同一にし，か つ直線性が得られるように設定した。

$2 \cdot 3$ 变位測定值による姿勢表示 シール满側面 の 4 個の変位センサ,アペックスシールのト部、下部

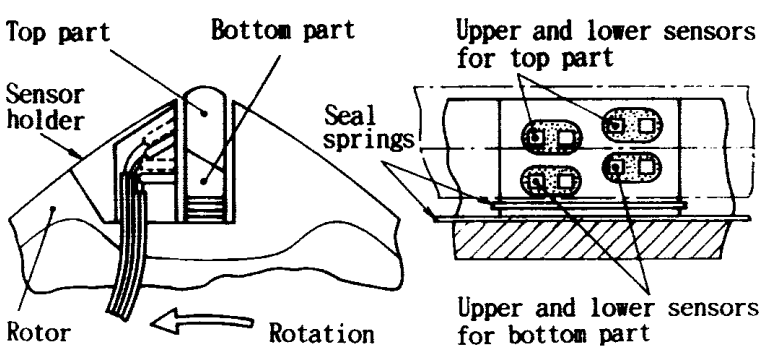

Fig. 5 Arrangement of displacement sensors for top and bottom parts of apex seal

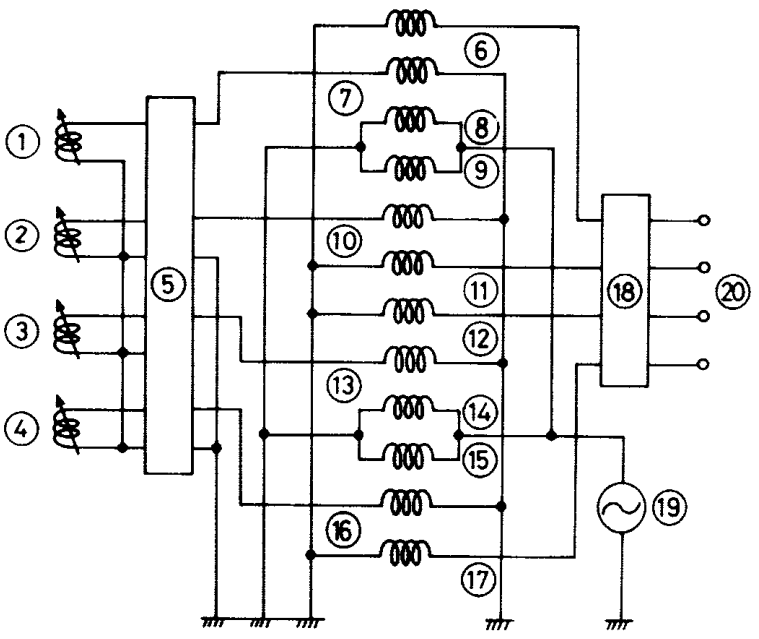

1. Upper sensor for top part of seal

2. Lower sensor for top part of seal

3. Upper sensor for bottom part of seal

4. Lower sensor for bottom part of seal

5. Slip ring

$6,11,12,17$. Receiving coils for respective sensors

$7,10,13,16$. Resonance coils for respective sensors

8, 9, 14, 15. Transmitting coils for respective sensors

18. Rectifier with shifter

20. Oscilloscope and digital recorder

Fig. 6 Circuit for four displacement sensors to measure apex seal behavior

シールの位置関係と寸法を図 7 に示す，変位测定值を 用いて任意の主軸角度についてアペックスシールのシ ール䘬での姿勢を模式図で表すために，次のような考 え方と方法で，プロッタ用のプログラムを組んだ。

（1）各変位測定值はそれぞれのセンサのシール瑇 の深さ力向のセンサ面の中心から垂值な力向にアペッ クスシールの被測定面に達する距離であると考える。

(2) シール溝でのアペックスシールのクリアラン ス抢よびシール淦幅と深さは，傾きを拡大して示すた めアパックスシールとそれらの寸法と比例的ではな w.

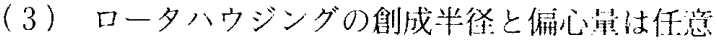




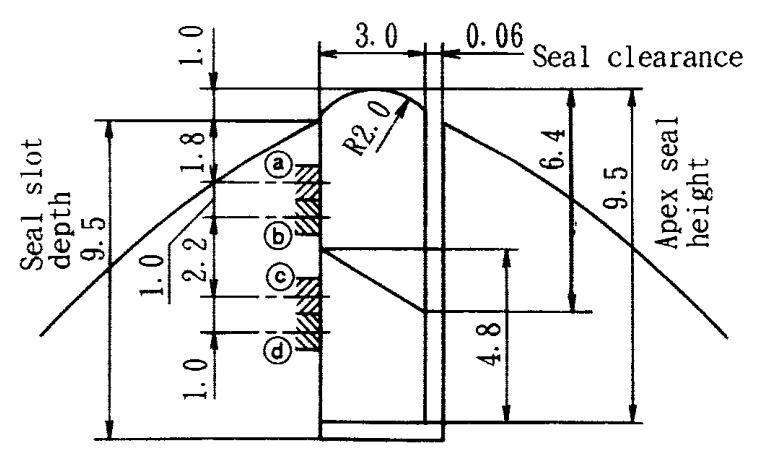

(a), (b), (c), (d) : Sensors

Fig. 7 Location of displacement sensors and dimensions of top and bottom parts of apex seal

に絔犬さするため，アペックスシール寸法と必ずしも同 比率ではない。

（4）上部シールのシール溝側面に刘する変位か

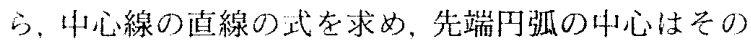
線上にあるので、鴻がトロコイドの平行曲線に接す るまで移動させる。すなうち，図形的に明らかに離れ た位置から，中心線上を一定の微小な変位で移動させ， 交点の解の最小佔を求め，近似解とする。它の接した 订弧の中心小ら部シール作図の開始点を求める。

（う）下部シールの偝側面に対する傾きを求め，そ の傾きを保ったまま，下部シールが上部シールの斜め の底部に接するまで移動させる。解法は(4)と问様。

$2 \cdot 4$ 実験条件 エンジン回転速度 1000 ～ 000 rpmについて，それぞれ無負荷から全負荷まで $1 / 4$ 負 荷ごとの運転を行った。シール類の潤滑油は, マッダ 社製 $13 \mathrm{~B}$ 形ロータリエンジンの1ロータ当たりに必 要とされている量(7)を供給した。冷却水と潤滑油温 度はともにほ傿 $80^{\circ} \mathrm{C}$ に保った。

\section{3. 実験結果および考察}

$3 \cdot 1$ 変位と挙動の概説 $3000 \mathrm{rpm}, 4 / 4$ 貝荷の

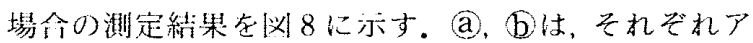
ペックスシールの上部シールの上下，(d，〔は下部シ ールの上トの変位セン州(図 7 と対応)の変位を示す。 トレースが酫くなっているときは, シール溝のリーデ イング側面に，低くなっているときは，トレーリング 側面に接近している状熊である。タイムマークとトり ガ信号は被测定アペックスシールが吸排気口側のトロ コイド短蟿の位罱 $\left(810^{\circ}\right)$ に設定してある。270過ぎ を見てみると，a，b，的がリーディング側に接近し， すがトレーリング側に谷っている。このことより上部 シールケはほほ斗行な状態でシール溝のリーディング

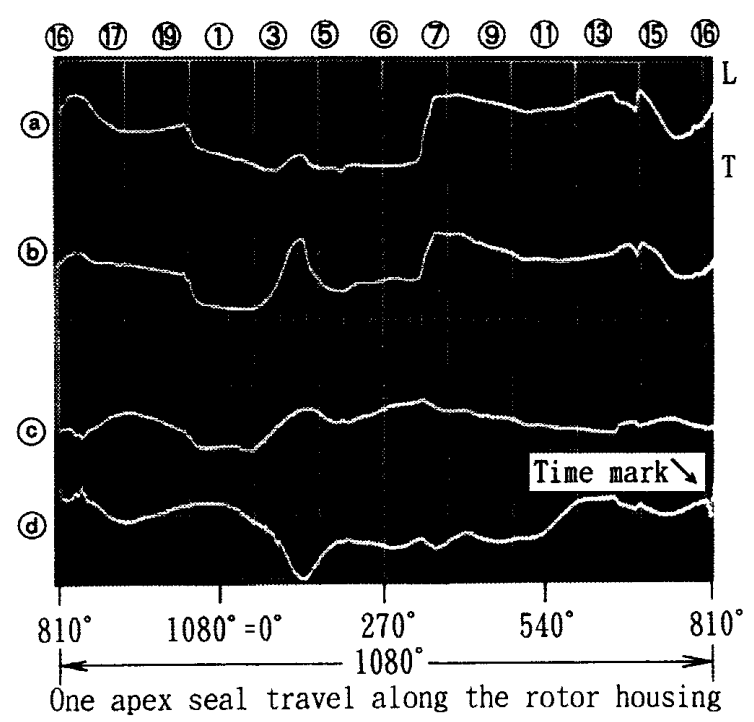

Fig. 8 Measured displacements of top and bottom parts of apex seal at $3000 \mathrm{rpm}$ full load

側に接し，下部シールは前傾していると考えられる。 このような变位の測定續果のみでは，アペックスシー ルの姿勢を詳練に把握することは容易ではない。

そこで，図 8 に示す $3000 \mathrm{rpm}$ 全负荷の場合につい て，测定したアペックスシールの変储を2・3節で示し た方法でパーソナルコンピュータとプロッタによって 表したアペックスシールのシール溝での挙動の模式図 图9に示す。また，先のロータハウジングトのアペ ックスシール位置でのアペックスシールのリーディン グ側とトレーリング側の作動室压も示す. 図 8,9 中 の(1)〜20によって測定した変位とアペックスシールの 姿勢を対応させてある。なお，アペックスシールの举 動の模式図はトロコイド短軸近傍は重なる部分が生じ てしまうため，主軸角度で $90^{\circ}$ ，その他の位置では $45^{\circ}$ おきに示してある。また，作動窒压はトロコイド曲線 の法線方向の長さで亦してある。次に，テペックスシ ールの(1)〜20までの姿勢を順を追って見ていく。

(1), (2)の姿勢はアペックスシールのリーディング作

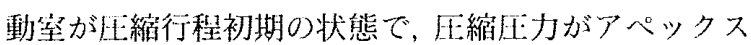
シールのリーディング側面に作用するため，上部シー ルはトレーリング溝側通にほほ平行に密着している。 そのため，良好な気密が行われていると㭳えられる。 一力，下部シールはドのリーディング側の角がリー ディング䩘側面に接触し，上方のリーブィング側の角 が上部シール下ううの斜面のリーディング側に接触し て、後に傾いた姿樊になっていて，面接触状態は得ら れていない。(3)になると，上部シールは後ろに傾き， 下部シールが前に傾いた状態，寸なわち，上部シール 


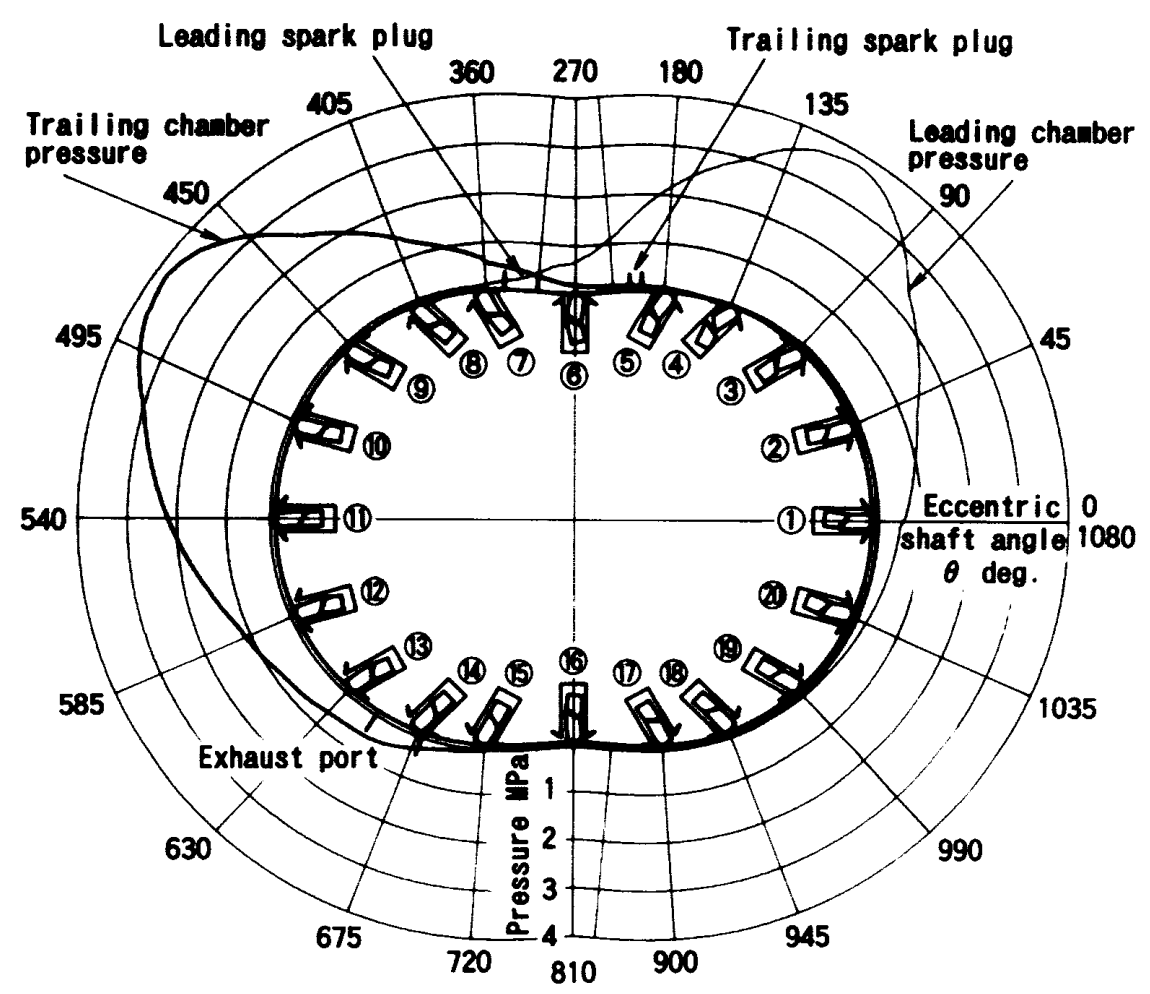

Fig. 9 Apex seal behavior versus mainshaft angle plotted by the aid of computer from measured displacements together with leading and trailing chamber pressures at $3000 \mathrm{rpm}$ full load

がシール溝のトレーリング溝側面の先端に奇り掛か り、下方が下部シール斜面のトレーリング部を押し, 下部シールの上方をシール溝のリーディング側へ押し やるために, 下方のトレーリング側の角がシール溝の トレーリング側に接している状態になっている. (3)近

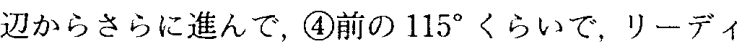
ング作動室が最高圧力になり，それまでのアペックス シール姿勢の極限に達している。 その後は，(5)姿勢 のように, (6)あたりまで, 下部、上部シールともにそ の姿勢の傾きが少し緩くなっている。これらの一連の 姿勢変化が生じる原因は, アペックスシールのリーデ イング作動室が圧縮から膨張行程へと変わり,アペッ クスシールをロータハウジング面へ押しつけるガス压 力による有効押しつけ力が変化し，それに伴って摩擦 力が変化し，アペックスシールが傾いた状態では摩擦 カがシール溝のトレーリング側先端を支点としたモー メントの変化をもたらすからである。(3)の少し前から (4)、(5)にかけての気密の特に重要な高作動室厅:の)領域 で, 期待されるような面接触気密が得られていないこ とがわかる。

続いて、（6)あたりまでの姿勢から一転して(7)のよう な姿勢に移行している。すなわち，上部シールがシー ル溝のリーディング側面にほぼ平行な状態で接触し，
ト部シールのに汅のリーディング角部がシール溝のリ ーディング側面に, 同じくトレーリング部が上部シー ルの下方のトレーリング角に, さらに, 下方のトレー リング角がシール溝のトレーリング側面に接触してい る状態になっている。この移行は，トレーリング作動 室の厌縮行程中の压力がリーディング作動室の排気行 程中の圧力よりも低い状態から，高低関係が逆転して， トレーリング作動室の圧力がリーディング作動室の㾏 力より高くなるために生じている。この作動察压の逆 転は压力線戍から $315^{\circ}$ 過ぎに生じていることがきか る. (6)の姿勢から(7)の姿勢への移行で，上下一体形う ペックスシールの場合に生じることがあった移行後の シール溝のリーディング側先端部を支点としたアペッ クスシールのびびり現象(5)は，図8を見ればおかるよ うに，このような上下斜分割 3 片式では生じないこと がわかった。

(7)，(8)，(9)と，ト部シールはほとんど(7)の姿勢のま まで，面接触状態が保たれているが，下部シールは下 方のトレーリング角がシール溝のトレーリング側面か ら少しずつ離れている。上部シールはアペックスシー ルのリーディング作動室の高王領域で顕著に後ろに傾 くのに対して，トレーリング作動室の高任領域ではほ とんど傾かないで，予想に反して，ほぼ面接触状態に 
なっていることがわかった。(10)あたりから(11)，(12)，(13) と上部シールは徐々に前傾姿勢の傾向になり，上方が シール溝のリーディング側面の先端に接近し，下方の トレーリング任がシール溝のトレーリング側面から浮 いた状態になっている。一力, 下部シールは回あたり

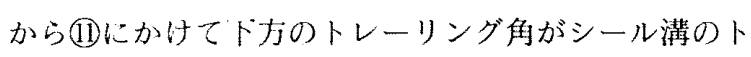
レーリング側面から離れ，前傾姿勢が緩くなり，(1Dで は, 次の姿勢への移行前の状態で, シール溝のリーデ イング側にやや前傾して接近している。続いて，下部 シールは(12)から(13あたりにかけて次第に後ろに傾いた 姿勢になっている。このように下部シールが前傾姿勢 から後傾姿勢になるのは，(12，(13)と上部シールの前傾 が增した姿勢になり，上部シール下うの斜面に下部シ ールがスプリングで押し付けられているため，下部シ ールが上部シールの斜面のトレーリング角に接してい た状態からリーディング角に接するようになるためで ある。

図 3 を参照するとわかるように, $649^{\circ}$ から排気行程 に入っているので，(19から(15)かけての姿勢は，アぺ ックスシールに作用するトレーリング側作動室0H业力 が低いため,アバックスシールがシール溝のリーディ ング僛配にほ平行な状態で接近しているのは，アペ ックスシールに作用するシール满に垂值力向の慣性力 がリーディング側面方向のためであると考光られる。

この角度領域では $2500 \mathrm{rpm}$ までは上部シールは後傾 し、下部シールは少し前傾しているが, $3000 \mathrm{rpm}$ あ たりから回転速度が高くなるにつれて，平行になり， 接近する程度も增している。また，負荷の違いによっ て生じると孝えられるリーディング作動室の吸気厌の 影響も見られない。これらのことからも，慣性力によ るものであることがわかる。

リーディング傾面にほほほ斗行な状態で接していたは 部シールは, (16)では, シール溝のリーディング側面方 向のシール溝に垂百方向の慣性力が負から正に変わる 変曲点で、荅となり、下部シールが上方のリーディン グ角で上部シール下うの斜面のリーディング部分を押 すため，上部シールは前傾し、シール溝のリーディン グ側面の先端によりかかり，下方がトレーリング側面 からも、リーディング側面からも浮いた状態になって いる，下部シールは、トカのリーディング角で上部シー ル下犼の斜面のリーディング部分を支え，下方のリー ディング解がシール满のリーディング側面に接触し， 後傾している.

(17)，(18)の領域では，上部シールはシール溝のリーデ イング儧面の先端から離れ，やや後傾した姿勢になり， それに伴って、下部シールは前傾姿勢になり，上部シ
ール，下部シールともに斜面のトレーリング部が互い に接触した状態になっている。 (191は，吸気口が閉じた 泊後で，上部シールはシール淦に平行な姿勢で,リー ディング側面からもトレーリング側面からもほほ均等 に離れた清の中央に位置し、下部シールがシール溝の リーディング側面に接近した状態で，わずかに後傾し た姿勢になっている。 (20は, アペックスシールのトレ ーリング作動室の吸気口が開いた $\left(1022^{\circ}\right)$ 直後であ る.また、リーディング作動室が压縮行程初期の状態 で, 压縮圧力がアペックスシールのリーディング側面 に作用し始め，上部シールが(1)のようにトレーリング 溝側面にほぼ平行に密着する前段階で，スプリングで 押された下部シールが上部シールの斜面のリーディン グ側を押すために，上部シールの下方がシール溝の卜 レーリング側に移動している。一方, 下部シールは下 方のリーディング側の角がリーディング溝側面に接触 し，上ガのリーディング側の角が、部シール下方の斜 酒のリーディング側に接触して, 後ろに傾いた姿勢に なりている。

$3 \cdot 2$ 回転速度の影響问転速度のアペックスシ 一ル上トシールの変位とアペックスシール姿勢に及峮 寸影響を $2 / 4$ 負荷の場命について，そ机ぞれ，図 10 と 四 11 亿示吉。図 $1001000 \mathrm{rpm}$ を除く问転速度の $0^{\circ}$ と270 とのほほ中間で, 上部シールの下方の変位 がリーディング側に山状に現れ，下部センサのド方の 変位がトレーリング側に谷状に現れている。これら は, リーディング作動室の最大压力時に生じる变位で, 変位の時期は回転速度の影響をほとんど受けていない ことがわかる。この時期は $115^{\circ}$ 近辺で, 为 $110135^{\circ}$ のアペックスシール姿勢に示されているように，上部 シールは後傾し，下部シール片は前傾している. 1000 $\mathrm{rpm}$ の場合を除くと差異はほとんど認めら机ない。

図 $100270^{\circ}$ 過ぎを見ると，上部シールの上力およ びト方の変位がトレーリング側からリーディング側へ と変位する第二次気密面の移行時期は回転速度が高く なるとともに遅れていることがわかる。これは、シー ル湿に直角力向の慣性力がトレーリング力向に作用寸 るため，回転速度が就くなると，慣性力が大きくなり， 移行時期を遅らせるためである。一方，下部シールは， その上部シールの移行時期前後では, 四 11 に示され ているように, $1000 \mathrm{rpm}$ の場合を除いて, 前傾姿勢 のままで, 㩆著な変位変化は生じていないが, 回転速 度が部くなると，上方がリーディング側に下方がトレ ーリング側に，それぞれ，やや瓷位が大きくなる傾向 にある。

低回転速度領域では，図 $100540^{\circ}$ と $810^{\circ}$ のほほ 


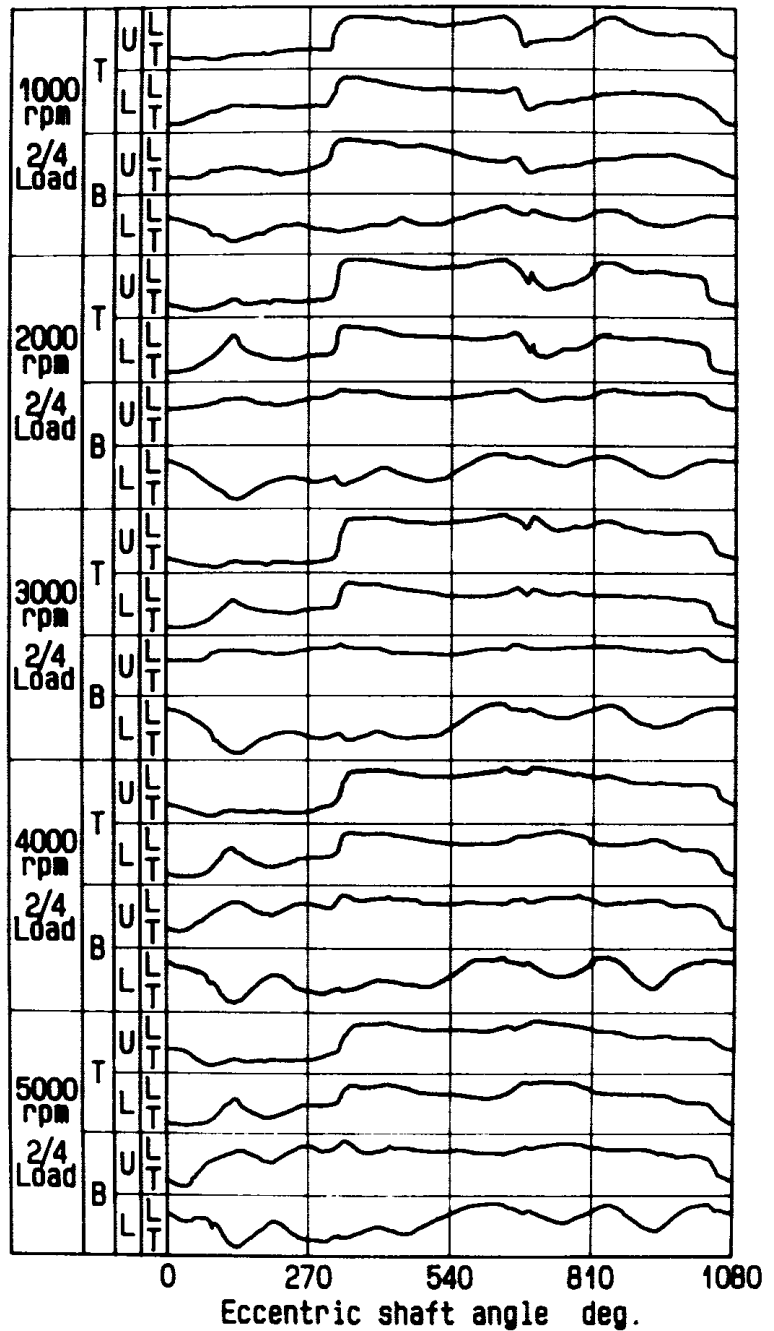

$T$ :Top part U:Upper sensor L:Leading side

$B$ :Bottom part L:Lower sensor T:Trailing side

Fig. 10 Effect of speed on measured displacements of top and bottom parts of apex seal at $2 / 4$ load

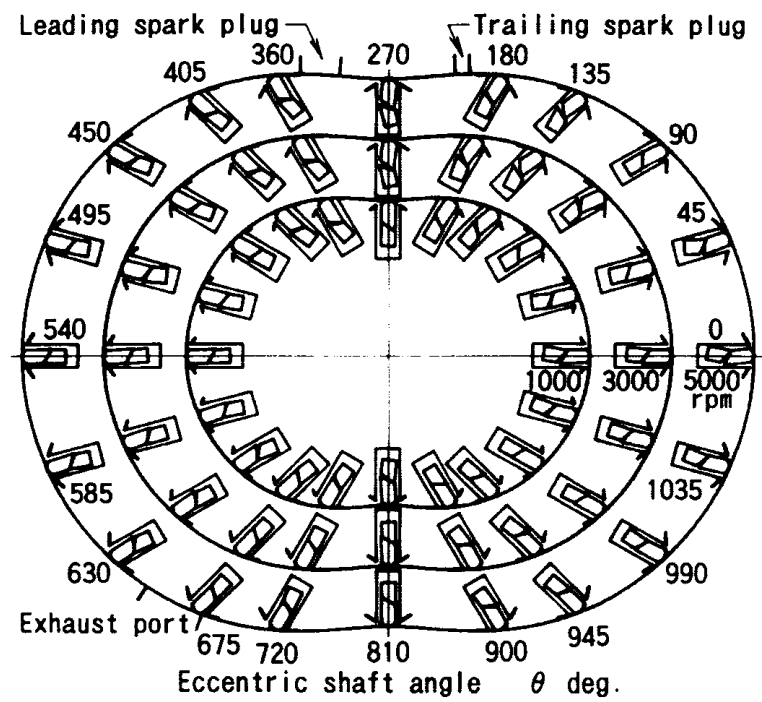

Fig. 11 Effect of speed on apex seal behavior for its travel on rotor housing at $2 / 4$ load

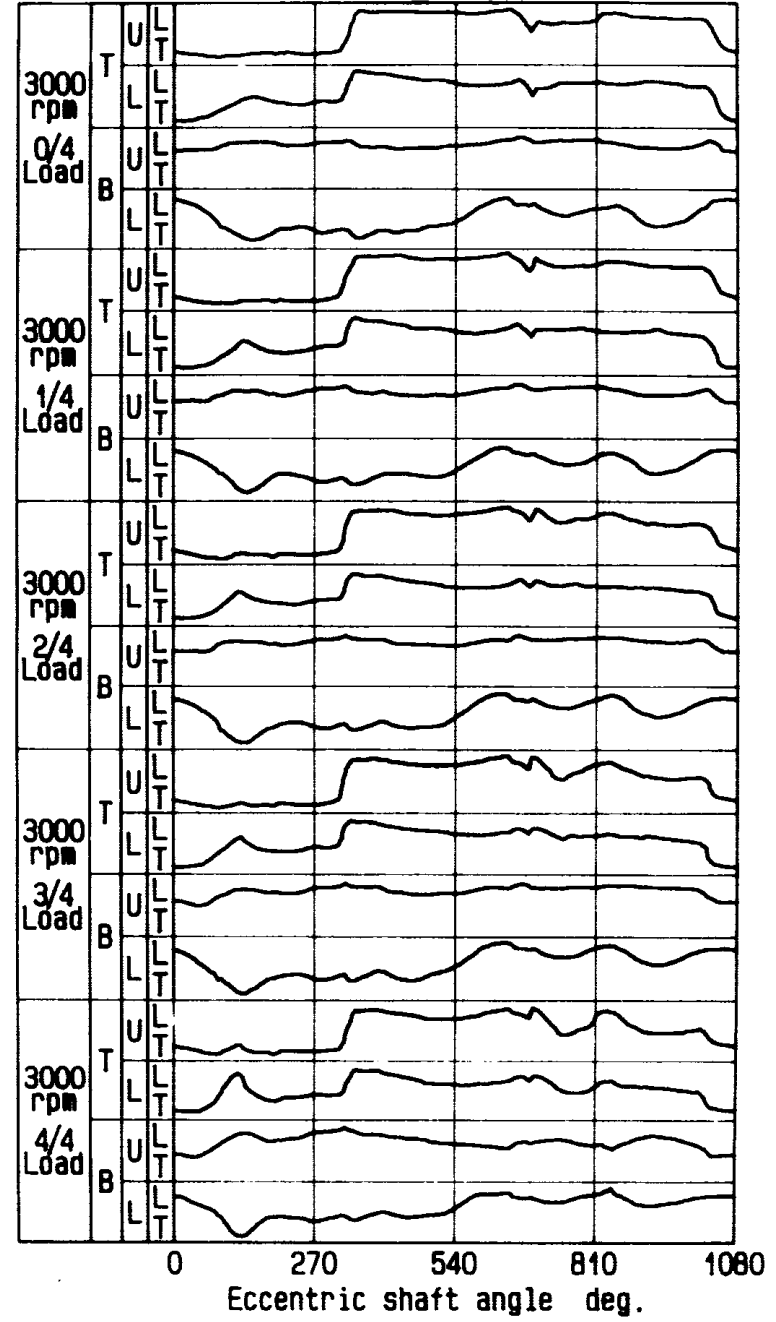

$T$ :Top part U:Upper sensor L:Leading side $B$ :Bottom part L:Lower sensor $T$ :Trailing side

Fig. 12 Effect of load on measured displacements of top and bottom parts of apex seal at $3000 \mathrm{rpm}$

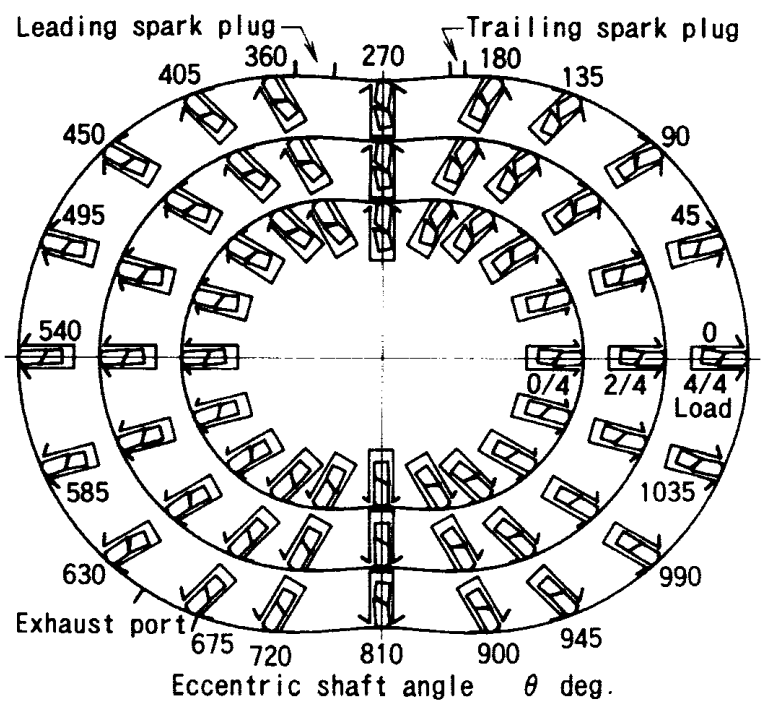

Fig. 13 Effect of load on apex seal behavior for its travel on rotor housing at $3000 \mathrm{rpm}$ 
中間位置で上部シールの上方と下方の変位がリーディ ング側からトレーリング側へ生じているが, 回転速度 が高くなるにつれてリーディング僋への変位が生じな くなっている.これは, 排気行程のためにトレーリン グ作動室の圧力が低下するため，ガス圧力によるリー ディング溝側面方向の押し付け力が小さくなり，トレ ーリング方向に作用するロータハウジングしゅう動面 とのトレーリング側方向の摩擦力が, リーディング方 向の慣性力より低回転では大きいが，回転速度が高く なると慣性力が勝るためである。図 10 の $1080^{\circ}$ の少 し前の $1035^{\circ}$ ありで上部シールの上方と下方がり ーディング側からトレーリング側入変位している。こ の変位は回転速度の影響はほとんど受けていない。リ 一ディング作動室が圧縮行程初期の状態で，括にに圧 力によって生じる変位であるためである、

$3 \cdot 3$ 負荷の影響 負荷のアペックスシール上下 シールの変位とアペックスシールの挙動に及ぼす影響 を $3000 \mathrm{rpm}$ の場合について，それぞれ，図 12 と図 13 に示す。図 12 の各負荷において $0^{\circ}$ と $270^{\circ}$ とのほ ほ中間で, 上部シールの下方の変位がリーディング側 に山状に現れ、下部シールの変位がトレーリング側に 谷状に現れている変位は, 負荷が增すとともに, 大き くなっている。これらは，トレーリング作動室の最大 压力時に生じる変位であるため, 負荷が増すと圧力が 高くなり，压力による押し付け力が増し，摩擦による シール湿のトレーリング先端を支点としたモーメント が大きくなり，図 13 の $135^{\circ}$ のような上部シールが後

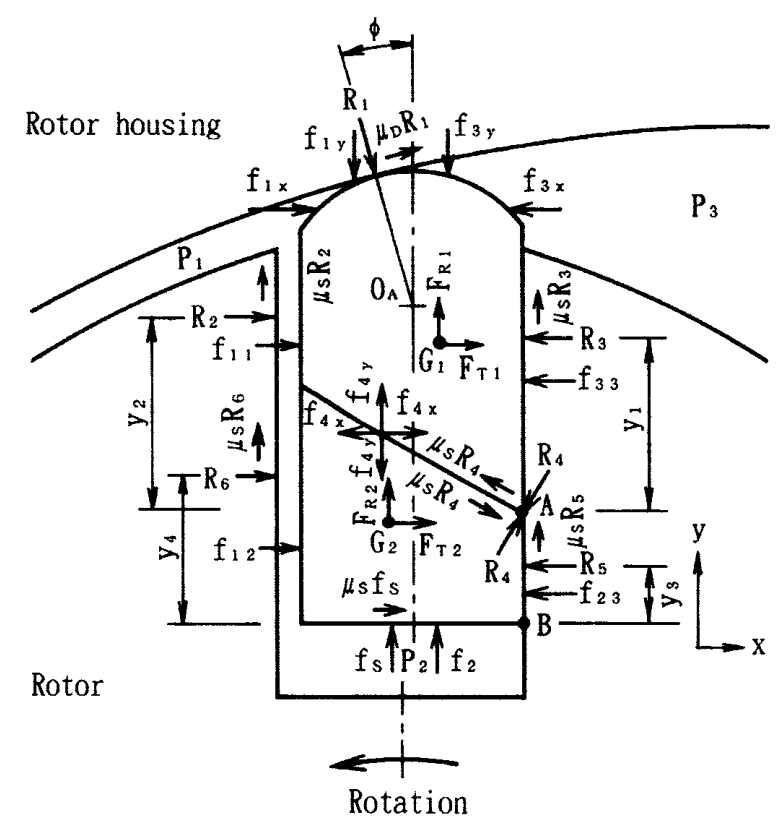

Fig. 14 Forces acting on slanted horizontal split apex seal
傾した姿勢になり，上部シールの下方のトレーリング 部で下部シールの上方がリーディング側に押され，下 部シールの前傾が増した姿勢になることがわかる。

図 12 の $270^{\circ}$ 過ぎの上部シールの上方および下方が トレーリング側からリーディング側へと咨位する第二 次気密面の移行時期は, 負荷の影響はほとんど受けて いなく，図 13 の $360^{\circ}$ の姿勢のように, 上部シールは シール淸のリーディング側面に面接触し, 下部シール の前傾姿勢にも変化は生じていない. 図 12 の $1035^{\circ}$ あたりで上部シールの上方と下方のリーディング側か らトレーリング側への変位は，おもに圧縮圧力による ため，偩荷が增すと，時期が早まり，図 13 を見てもわ かるように,トレーリング側により接近し, 密着して いる.

$3 \cdot 4$ 力学的解析 上下斜分割アペックスシール がロータハウジング内面上をしゅう動するとき，各場 所でどのような力が作用するのか，また，それらの大 小関係からシールの姿勢を理解するための静力学的解 析を示す。シール溝でのに下シールの姿勢は図 9 から もわかるように互いに逆の傾きで斜面部が接している 二つの場合, 寸なわち, 上下の斜面部の接触点(線)が リーディング側で接触している場合とトレーリング側 で接触している場合に大別できる。これらの代表例と して，後者の場合を示す．図 14 に示すような上部，下 部シールに作用する諸力と図 15 に示すような理力分 布, 寸法および位置関係から, 各シールの $x, y$ 方向 の力と点 A, Bにおけるモーメントの静的な釣合い(8) は，それぞれ式(1)〜 (6)のように表される. 各位置 での反力とそれによって生じるシールの変位の方向お

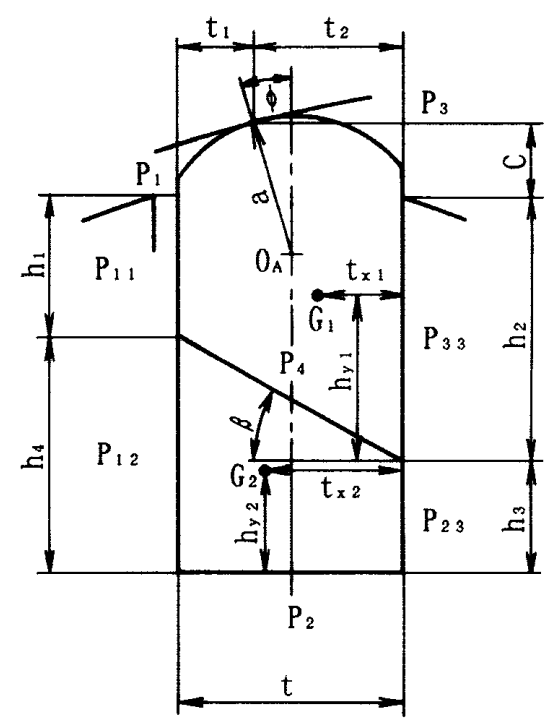

Fig. 15 Slanted horizontal split apex seal showing dimensions and pressures 
よび変位の起因となる各力の大小関係を求めることが できる。

$$
\begin{aligned}
& \text { 上部シールについては } \\
& \sum F_{x 1}=R_{1}\left(\mu_{D} \cos \phi+\sin \phi\right)+R_{2}-R_{3} \\
& -R_{4}\left(\mu_{S} \cos \beta-\sin \beta\right)+F_{T 1}+f_{11}+f_{1 x} \\
& +f_{4 x}-f_{3 x}-f_{33}=0 \\
& \sum F_{y_{1}}=R_{1}\left(\mu_{D} \sin \phi-\cos \phi\right)+\mu_{S} R_{2}+\mu_{S} R_{3} \\
& +R_{4}\left(\mu_{S} \sin \beta+\cos \beta\right)+F_{R 1}+f_{4 y} \\
& -f_{1 y}-f_{3 y}=0 \\
& \sum M_{A}=R_{1}\left\{\left(C+h_{2}\right) \sin \phi-t_{2} \cos \phi\right. \\
& \left.+\mu_{D}\left[\left(C+h_{2}\right) \cos \phi+t_{2} \sin \phi\right]\right\} \\
& +R_{2}\left(\mu_{s} t+y_{2}\right)-R_{3} y_{1}+F_{R 1} t_{x 1} \\
& +F_{T 1} h_{y 1}-f_{33} h_{2} / 2+f_{4 y} t / 2 \\
& +f_{4 x}\left(h_{2}-h_{1}\right) / 2+f_{11}\left[\left(h_{2}-h_{1}\right)+h_{1} / 2\right. \\
& +f_{1 x}\left(h_{2}+C / 2\right)-f_{1 y}\left(t_{2}+t_{1} / 2\right) \\
& -f_{3 x}\left(h_{2}+C / 2\right)-f_{3 y} t_{2} / 2=0 \\
& \text { 下部シールについては } \\
& \sum F_{x 2}=R_{4}\left(\mu_{S} \cos \beta-\sin \beta\right)-R_{5}+R_{6}+F_{T 2} \\
& +\mu_{S} f_{S}+f_{12}-f_{4 x}-f_{23}=0 \\
& \sum F_{y 2}=-R_{4}\left(\mu_{S} \sin \beta+\cos \beta\right)+\mu_{s} R_{5}+\mu_{s} R_{6} \\
& +F_{R 2}+f_{S}-f_{4 y}+f_{2}=0 \text {. } \\
& F_{R}=M \omega^{2}\left[R_{g} / 9+e \cos (2 / 3) \theta\right] \quad(y \text { 万向が正) } \\
& F_{T}=-M \omega^{2} e \sin (2 / 3) \theta \quad(x \text { 方向が正 })
\end{aligned}
$$

\section{4. まと め}

新しい方式の実験用片持式ロータリエンジンを開発 した. 3 片式上下斜分割アペックスシールの第二次気
密面の挙動を 4 個のセンサで変位測定し, 姿勢を模式 図で表示し，以下のことが明らかになった。

（1）上部シールはアペックスシールのリーディン グ作動室の高圧領域では, 顕著に後ろに傾き, 線接触 状態の気密になるのに対して,トレーリング作動室の 高圧領域では，ほとんど傾かないで，ほぼ面接触状態 になっていて，良好な第二次気密面が得られている。

（2）従来の 2 個の変位センサによる測定では, 上 部シールがシール溝側面と平行な状態, すなわち, 面 接触気密が得られるのは, 作動室のトレーリングアペ ックスシールが圧縮行程初期のみであると推測されて いたが, リーディングアペックスシールが膨張行程の 比較的長い期間にも面接触気密がほほ保持されてい 万.

（3）上下一体形アペックスシールでは，生じる場 合があった, 点火プラグ側短軸後の第二次気密面の移 行後のシール溥のリーディング側先端部を支点とした びびり現象は上下斜分割 3 片式では生じない.

(4) 上部シールと下部シールは, シール溝での傾 きはほとんどの場合，逆の傾き角度を成している.

本研究を進めるに当たり, マツダ(株)から, エンジ ン部品の援助をいただいた，また，当時本学大学院生 遠藤太郎, 沢井正紀, 卒研生 大石拓也, 南川基治の 各位にエンジンならびに測定系の製作に協力していた だいた。ここに記して感謝の意を表す。

\section{文献}

(1) Meinrad, K. E. and Edward, D. K., SAE Paper, No. 730117 (1973).

（2）遠藤貞・金丸皚之助，セラミックス，6-10（1971），146149 .

(3) Fujimoto, Y., ほか 3 名, SAE Paper, No. 870446 (1987).

(4) Hamady, F., ほか3 名, SAE Paper, No. 910893 (1991).

（5）松浦健児・ほか2 名, 機論, 58-556, B (1992)，294-301.

（6）松浦健児 - 寺崎和郎, 機論, 56-526, B (1990), 242-247.

(7) Stubblefield, M. and Haynes, J. H., Mazda RX-7 '86thru'91, (1991), 57, Haynes.

(8) Martin, A. R. and Sadler, J. P., Proc. 5th World Cong. Theory Mach. Mech., (1979), 1240, publ. ASME. 